NOTE

\title{
PCR assay for discriminating between infectious hypodermal and hematopoietic necrosis virus (IHHNV) and virus-related sequences in the genome of Penaeus monodon
}

\author{
Kathy F. J. Tang*, Solangel A. Navarro, Donald V. Lightner \\ Department of Veterinary Science and Microbiology, University of Arizona, Tucson, Arizona 85721, USA
}

\begin{abstract}
We developed a PCR assay that can detect infectious hypodermal and hematopoietic necrosis virus (IHHNV) but that does not react with IHHNV-related sequences in the genome of Penaeus monodon from Africa and Australia. IHHNV is a single-stranded DNA virus that has caused severe mortality and stunted growth in penaeid shrimp. Recently, IHHNV-related sequences were found in the genome of some stocks of P. monodon from Africa and Australia. These virus-related sequences have a high degree of similarity ( 86 and $92 \%$ identities in nucleotide sequence) to the viral genome, which has often generated false-positive reactions during PCR screening of these stocks. For this assay, a pair of IHHNV primers (IHHNV309F/R) was selected. The sequences of these primers match $(100 \%$ of nucleotides) the target sequence in IHHNV, but mismatch 9 or 12 nucleotides of the genomic IHHNV-related sequences. This PCR assay was tested with various IHHNV isolates and with a number of samples of shrimp DNA that contained IHHNV-related sequences. This assay can reliably distinguish IHHNV DNA from shrimp DNA: it only detects IHHNV. Also, this pair of primers was included in a duplex PCR to detect IHHNV and simultaneously determine the presence of an IHHNV-related sequence. Using these primers, the PCR assay has a sensitivity equivalent to a PCR assay commonly used for detecting IHHNV in Litopenaeus vannamei, and can be used for routine detection.
\end{abstract}

KEY WORDS: Infectious hypodermal and hematopoietic necrosis virus (IHHNV) $\cdot$ IHHNV-related sequences · Penaeus monodon $\cdot \mathrm{PCR}$

\section{INTRODUCTION}

Infectious hypodermal and hematopoietic necrosis virus (IHHNV) is an important agent of disease in cultured penaeid shrimp. This virus caused severe mortalities in Litopenaeus stylirostris from 1980 to 1990 (Lightner et al. 1983a,b), but this species has become more tolerant to IHHNV infection and significant mortalities have not been noted in recent years (MoralesCovarrubias et al. 1999, Tang \& Lightner 2002). In Litopenaeus vannamei and Penaeus monodon, IHHNV does not typically cause mortality, but it can result in runt deformity syndrome, which greatly reduces growth and causes cuticular and rostrum deformities (Bell \& Lightner 1984, Kalagayan et al. 1991, Primavera \& Quinitio 2000).

IHHNV is an icosahedral, non-enveloped parvovirus with a single-stranded, $4.1 \mathrm{~kb}$ DNA genome comprised of 3 large open reading frames (ORF) (Bonami et al. 1990, Shike et al. 2000). It is closely related to the mosquito viruses and is placed as a tentative species within the genus Brevidensovirus (Fauquet et al. 2005).

Through PCR and DNA sequencing, IHHNV was detected in Penaeus monodon from SE Asia, and 2 variants (represented by Thailand and Philippines isolates) were identified by phylogenetic analysis (Tang 
et al. 2003). PCR assays also detected IHHNV-related sequences: Type A was found in samples from Madagascar and Australia (Krabsetsve et al. 2004, Tang \& Lightner 2006), and Type B was found in samples from Tanzania and Mozambique. Neither type was found to be derived from an infectious virus, and Type A was determined to be part of shrimp genomic DNA.

In this study, we developed a PCR assay using primers that only detect the IHHN viral sequence and do not react with IHHNV-related sequences. This assay will be useful for developing specific-pathogen free (SPF) Penaeus monodon with the candidate stocks from Africa or Australia.

\section{MATERIALS AND METHODS}

IHHNV DNA. Total DNA was extracted from either gills or pleopods of shrimp using a High-pure DNA template preparation kit (Roche Bioscience). IHHNVinfected Litopenaeus vannamei were collected from Hawaii, Belize, and Brazil (Table 1). A sample of Marsupenaeus japonicus was infected with IHHNV and also included in this study. Infected L. stylirostris were collected from New Caledonia. For these samples, the presence of IHHNV DNA was determined

Table 1. Origin, year of collection, and species of shrimp (Litopenaeus vannamei, L. stylirostris, Marsupenaeus japonicus, and Penaeus monodon) from which IHHNV and IHHNV-related sequences were studied

\begin{tabular}{|c|c|c|c|c|}
\hline No. & Origin & Year & Species & $\begin{array}{l}\text { Type of IHHNV or } \\
\text { related sequence }\end{array}$ \\
\hline 1 & Hawaii & 1987 & L. vannamei & Hawaii \\
\hline 2 & Belize & 2005 & L. vannamei & Hawaii \\
\hline 3 & Brazil & 2005 & L. vannamei & Hawaii \\
\hline 4 & Hawaii & 2005 & M. japonicus & Hawaii \\
\hline 5 & Philippines & 1996 & P. monodon & Hawaii \\
\hline 6 & New Caledonia & 2004 & L. stylirostris & Hawaii \\
\hline 7 & Mauritius & 2000 & P. monodon & Type A \\
\hline 8 & Madagascar & 2001 & P. monodon & Type A \\
\hline 9 & Madagascar & 2001 & P. monodon & Type A \\
\hline 10 & Madagascar & 2003 & P. monodon & Type A \\
\hline 11 & Malaysia $^{a}$ & 2004 & P. monodon & Types A and B \\
\hline 12 & Taiwan & 2001 & P. monodon & Thailand \\
\hline 13 & Thailand & 2002 & P. monodon & Thailand \\
\hline 14 & Tanzania & 2001 & P. monodon & Types A and B \\
\hline 15 & Tanzania & 2001 & P. monodon & Types A and B \\
\hline 16 & Tanzania & 2001 & P. monodon & Types A and B \\
\hline 17 & Tanzania & 2001 & P. monodon & Types A and B \\
\hline 18 & Tanzania & 2004 & P. monodon & Types A and B \\
\hline 19 & Mozambique & 2004 & P. monodon & Types A and B \\
\hline 20 & Fiji & 2004 & P. monodon & Not detected \\
\hline 21 & West Australia & 2004 & P. monodon & Type A \\
\hline 22 & West Australia & 2004 & P. monodon & Not detected \\
\hline
\end{tabular}

by PCR with IHHNVF/R1 primers, followed by DNA sequence analysis, as described by Tang \& Lightner (2006).

IHHNV-infected Penaeus monodon were collected from the Philippines, Taiwan, and Thailand. Their genotype was determined by PCR and DNA sequence analysis (Tang et al. 2003).

Penaeus monodon DNA containing IHHNV-related sequences. Total DNA was extracted from adult $P$. monodon collected from Mauritius, Madagascar, Malaysia (this sample of $P$. monodon originated from Africa), Tanzania, Mozambique, and Fiji, and from juveniles produced by broodstock originating from Australia. These shrimp contained IHHNV-related sequences as determined by PCR and DNA sequence analysis as described by Tang \& Lightner (2006). Results of bioassays confirmed that shrimp samples from Madagascar, Tanzania, Mozambique, and Australia were free of IHHNV.

Penaeus monodon samples from Andaman Sea. Two broodstock (Samples 1 and 4), a sample of eggs (Sample 2), and postlarvae (Sample 3) of P. monodon were sent from a farm in India. The broodstock were collected from different sites in the Andaman Sea. Eggs and postlarvae were produced in the farm by a wild-caught spawner.

PCR assays. For PCR assays performed in this study, PuReTaq ready-to-go PCR beads (Amersham Biosciences) were used. The PCR reaction contained $0.2 \mu \mathrm{M}$ of each primer, $10 \mathrm{mM}$ Tris- $\mathrm{HCl}$ (pH 9.0), $50 \mathrm{mM} \mathrm{KCl}, 1.5 \mathrm{mM} \mathrm{MgCl}$, $2.5 \mathrm{U}$ of Taq DNA polymerase, and $1 \mu \mathrm{l}$ of extracted DNA (100 to $\left.500 \mathrm{ng} \mathrm{ll}^{-1}\right)$. The sequences and target sites of the primers are listed in Table 2. For IHHNV309F/R, amplification was performed with the following cycling parameters: initiation denaturation at $94^{\circ} \mathrm{C}$ for 5 min, followed by 35 (or 40) cycles of $94^{\circ} \mathrm{C}$ for $30 \mathrm{~s}, 55^{\circ} \mathrm{C}$ for $30 \mathrm{~s}$, and $72^{\circ} \mathrm{C}$ for $30 \mathrm{~s}$, and a final extension at $72^{\circ} \mathrm{C}$ for $7 \mathrm{~min}$. For IHHNV389F/R, the annealing temperature was increased to $60^{\circ} \mathrm{C}$ and 35 cycles were performed. For duplex PCR with primers IHHNV309F/R and MG831F/ $R$, the reaction was carried out for 35 cycles of $30 \mathrm{~s}$ at an annealing temperature of $55^{\circ} \mathrm{C}$. Following PCR, an aliquot of the PCR products was analyzed in a $1.5 \%$ gel containing ethidium bromide, which was then photographed.

Determination of melting temperature $\left(\boldsymbol{T}_{\mathrm{m}}\right)$. The $T_{\mathrm{m}}$ of primers IHHNV309F and IHHNV309R with their target sequences in IHHNV, Type A and Type B IHHNV-related sequences was determined using the HyTHER program (SantoLucia 1998, Peyret et al. 1999) available from the HyTHER server (http:// 
Table 2. DNA sequence and binding sites of PCR primers used in this study

\begin{tabular}{|llcc|}
\hline Primer designation & Primer sequence & Nucleotide no. & GenBank accession no. \\
\hline IHHNV309F & 5'-TCCAACACTTAGTCAAAACCAA & 1936 & AF218266 \\
IHHNV309R & 5'-TGTCTGCTACGATGATTATCCA & 2244 & AF218266 \\
IHHNV389F & 5'-CGGAACACAACCCGACTTTA & 1400 & AF218266 \\
IHHNV389R & 5'-GGCCAAGACCAAAATACGAA & 1788 & AF218266 \\
MG831F & 5'-TTGGGGATGCAGCAATATCT & 2858 & DQ228358 \\
MG831R & 5'-GTCCATCCACTGATCGGACT & 3688 & DQ228358 \\
\hline
\end{tabular}

ozone3.chem.wayne.edu). Parameters used for $T_{\mathrm{m}}$ prediction were changed to take into account the reagents in the $\mathrm{PCR}$ reaction mixture. The concentrations of $\mathrm{NaCl}$ and $\mathrm{MgCl}_{2}$ were set as $0.05 \mathrm{M}$ and $0.0015 \mathrm{M}$, respectively. The concentration of both strands was set at $0.2 \mu \mathrm{M}$.

\section{RESULTS AND DISCUSSION}

We selected primers IHHNV309F/R from the left ORF region of the IHHNV genome, because this region has higher (8 and $14 \%$ ) variation in nucleotide sequence between virus and IHHNV-related sequences than does the right ORF (5 and 9\%) (Tang et al. 2003). The sequence of primer IHHNV309F is identical in 2 IHHNV isolates from Hawaii and Thailand (Fig. 1), and HyTHER revealed a predicted $T_{\mathrm{m}}$ of $58.7^{\circ} \mathrm{C}$. This primer had 8 nucleotides $(36 \%)$ mismatched to the Type A IHHNV-related sequence, with a predicted $T_{\mathrm{m}}$ of $8.1^{\circ} \mathrm{C}$. It had 4 mismatched nucleotides $(18 \%)$ with the Type B sequence, and a predicted $T_{\mathrm{m}}$ of $37.3^{\circ} \mathrm{C}$. Primer IHHNV309F would not efficiently anneal to either the Type A or the Type B sequences because their $T_{\mathrm{m}}$ were significantly decreased, in particular that of the Type A sequence. Primer IHHNV309R also had an identical sequence to that of both virus isolates, and the predicted $T_{\mathrm{m}}$ was $59.6^{\circ} \mathrm{C}$. This primer had $4(18 \%)$ and $5(23 \%)$ mismatched nucleotides to Type A and Type B sequences, and their $T_{\mathrm{m}}$ were also decreased to $34.2^{\circ} \mathrm{C}$ and $26.8^{\circ} \mathrm{C}$, respectively. These four $T_{\mathrm{m}}$ predicted between IHHNV309F/R and the 2 targeted (Type A and B) sequences were well below the annealing temperature $\left(55^{\circ} \mathrm{C}\right)$ used in the PCR assay. This may have pre- vented binding of the primers with the Type A and B IHHNV-related sequences. Thus, this pair of primers was specific to IHHNV isolates originating from the western hemisphere, the Philippines (Hawaii type), and from Taiwan and Thailand (Thailand type).

PCR assays with primers IHHNV309F/R were performed with DNA prepared from IHHNV-infected shrimp and from Penaeus monodon containing IHHNV-related sequences. The results showed that IHHNV was detected in the following infected shrimp: Litopenaeus vannamei and Marsupenaeus japonicus collected from Hawaii, L. vannamei from Belize and Brazil, L. stylirostris from New Caledonia, and P. monodon from the Philippines, Taiwan, and Thailand (Fig. 2A, Lanes 1 to 6, 12, and 13). This pair of primers did not react with either Type A or Type B IHHNVrelated sequences in $P$. monodon from Africa and Australia (Fig. 2A, Lanes 7 to 11, 14 to 22). We also increased the PCR cycling from 35 to 40 cycles for a greater sensitivity of detection, but the results were the same: only IHHNV was detected.

Primers IHHNV389F/R have been used for the detection of IHHNV in Litopenaeus vannamei and L. stylirostris. These primers were also selected from the left ORF and are $100 \%$ identical in target sequence between IHHNV and IHHNV-related sequences. Thus, they react to both IHHNV DNA and IHHNV-related sequences (Fig. 2B, Lanes 1 to 19, 21). Two Penaeus monodon samples (Fig. 2B, Lanes 20 and 22, from Fiji and Australia) did not react with either pair of primers, indicating that they were not infected with IHHNV, and did not contain IHHNV-related sequences. Not all, but a high percentage (16 out of 20), of the P. monodon from Australia were found to contain the Type A IHHNVrelated sequence (Krabsetsve et al. 2004).

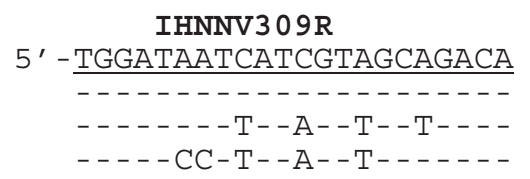

Fig. 1. Variation in nucleotide sequence among IHHNV isolates from Hawaii (Hi) and Thailand (Th) and the Type A and B

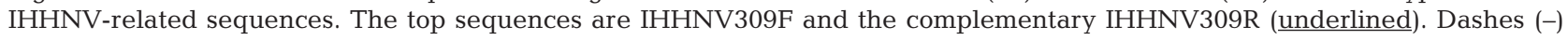
indicate the same nucleotide sequence 


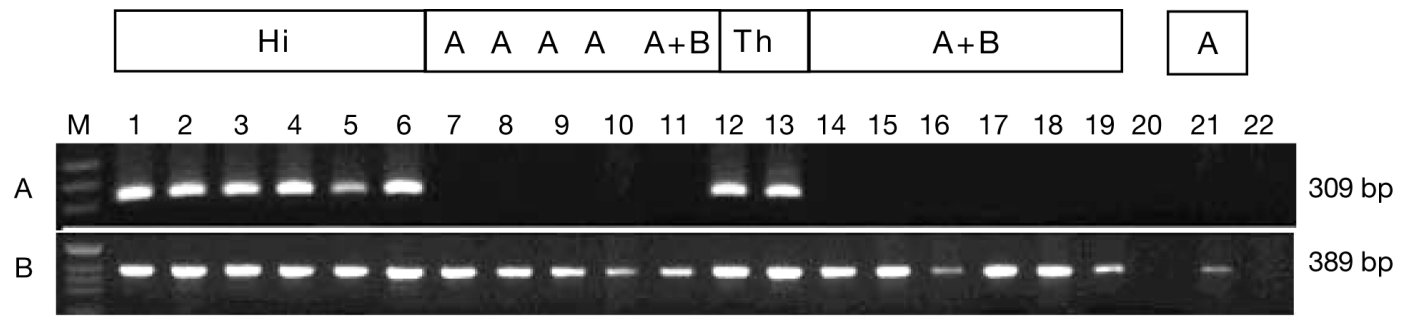

Fig. 2. PCR detection of IHHNV in penaeid shrimp: (A) amplified with primers IHHNV309F/R, (B) amplified with IHHNV389F/R. DNA was extracted from Litopenaeus vannamei from Hawaii (Lane 1), Belize (Lane 2), Brazil (Lane 3), Marsupenaeus japonicus from Hawaii (Lane 4), Penaeus monodon from the Philippines (Lane 5), L. stylirostris from New Caledonia (Lane 6), and P. monodon from Mauritius (Lane 7), Madagascar (Lanes 8-10), Malaysia (Lane 11, imported from Africa), Taiwan (Lane 12), Thailand (Lane 13), Tanzania (Lanes 14-18), Mozambique (Lane 19), Fiji (Lane 20), and Australia (Lanes 21 and 22). Hi: Hawaii-type

IHHNV; Th: Thailand-type IHHNV; A: Type A IHHNV-related sequence; A+B: Types A and B IHHNV-related sequences

The PCR assay with IHHNV309F/R was further tested in 48 Penaeus monodon broodstock from Mozambique. These shrimp contained integrated Type A IHHNV-related sequence, as determined by PCR assay using primers MG831F/R (Tang \& Lightner 2006); however, IHHNV was not detected (data not shown). Histological examination of 6 broodstock from the same population confirmed that they were not infected with IHHNV.

We developed a duplex PCR that amplifies the virusrelated sequence with primers MG831F/R together with primers IHHNV309F/R. This duplex PCR assay detected IHHNV and the genomic Type A IHHNVrelated sequence. A positive reaction with MG831F/R primers indicates that stocks from either Africa or Australia contain the Type A sequence. It is useful for monitoring both the presence of IHHNV and the origin of the stocks. This assay was tested with IHHNV and Penaeus monodon DNA from Africa and Australia. The results showed that samples from Hawaii, Belize, the Philippines, and Thailand were positive for IHHNV and yet did not contain the genomic Type A sequence (Fig. 3, Lanes 2 to 5). Samples of P. monodon with the Type A sequence from Madagascar, Tanzania, and Australia were not infected with actual IHHNV (Fig. 3, Lanes 7 to 11 ).

PCR assay with primers IHHNV309F/R was used to determine the presence of IHHNV in samples of Penaeus monodon collected from the Andaman Sea. All 4 samples tested positive (Fig. 4A) when using primers IHHNV389F/R, but only 2 (Samples 1 and 4) tested positive when using primers IHHNV309F/R (Fig. 4B). The 309 bp PCR fragments from Samples 1 and 4 were excised from the gel and sequenced. Sequence searches of Sample 1 using the basic local alignment search tool (BLAST) showed that this IHHNV was $98 \%$ identical to a Thailand isolate (GenBank accession no. AY362547), with an E-value of $6 \mathrm{E}-122$. Sample $4 \mathrm{IHHNV}$ was $99 \%$ identical to

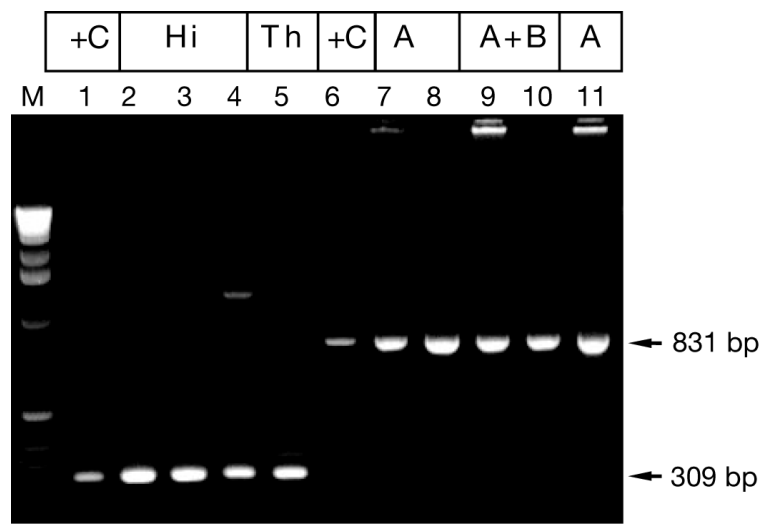

Fig. 3. Duplex PCR detection of IHHNV and Type A IHHNVrelated sequence in penaeid shrimp. Lane M: $1 \mathrm{~kb}$ DNA ladder. Lanes 1 and 6: positive control (plasmid DNA) for primers IHHNV309F/R and MG831F/R, respectively. DNA was extracted from Litopenaeus vannamei from Hawaii (Lane 2), Belize (Lane 3), and Penaeus monodon from the Philippines (Lane 4), Thailand (Lane 5), Madagascar (Lanes 7, 8), Tanzania (Lanes 9, 10) and Australia (Lane 11). Hi: Hawaii-type IHHNV; Th: Thailand-type IHHNV; A: Type A IHHNVrelated sequence; $\mathrm{A}+\mathrm{B}$ : Types $\mathrm{A}$ and $\mathrm{B}$ IHHNV-related sequences; + C: positive control plasmid

another Thai IHHNV (GenBank accession no. AY102034), with an E-value of 3E-124. This proves that primers 309F/R amplify infectious IHHNV. There was a $96 \%$ identity between Sample 1 and Sample 4 sequences. This is consistent with the fact that they were collected from 2 different sites $50 \mathrm{~km}$ apart. Samples 2 and 3 were not detected by primers IHHNV309F/R yet contain Type A sequence; both were amplified with primers MG831 in the duplex PCR (Fig. 4C). Sample 4 (identified as containing the Type A sequence) was also infected with the IHHNV, indicating that the presence of an integrated IHHNVrelated sequence cannot protect shrimp from IHHNV infection. Thus, P. monodon from Africa, Australia 


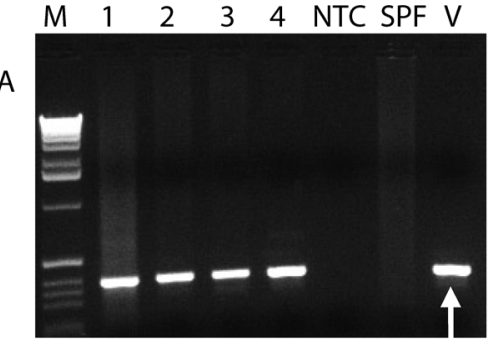

$389 \mathrm{bp}$
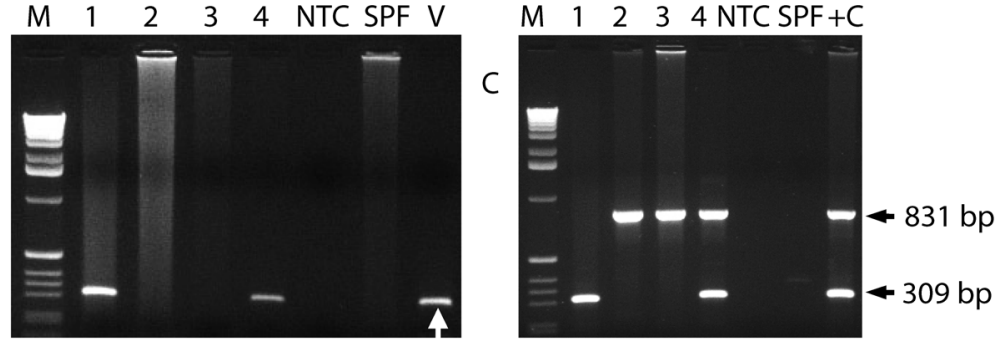

Fig. 4. PCR detection of IHHNV and Type A IHHNV-related sequence in Penaeus monodon from the Andaman Sea: (A) amplified with primers IHHNV389F/R, (B) amplified with IHHNV309F/R, (C) amplified with IHHNV309F/R and MG831F/R. Lane M: 1 kb DNA ladder; Lane 1: Broodstock No. 1; Lane 2: eggs; Lane 3: postlavae; Lane 4: Broodstock No. 2. NTC: non-template control; SPF: specific-pathogen-free Litopenaeus vannamei; V: purified IHHNV virions; +C: mixture of P. monodon DNA, Type A IHHNV-related sequence, and purified IHHNV virions

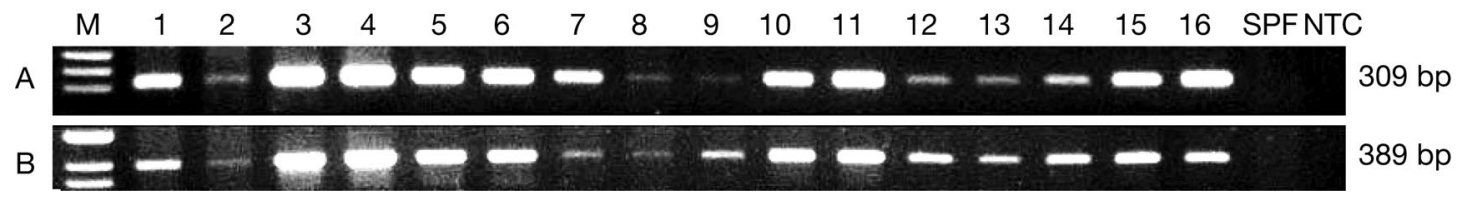

Fig. 5. PCR detection of IHHNV in Litopenaeus vannamei samples from Hawaii (Lanes 1-9) and Mexico (Lanes 10-16): (A) amplified with primers IHHNV309F/R, (B) amplified with IHHNV389F/R. NTC: non-template control; SPF: specific-pathogenfree L. vannamei

and Andaman Sea will still need to be monitored for the presence of IHHNV.

Primers IHHNV309F/R can also be used to detect IHHNV infection in Litopenaeus vannamei with a sensitivity equivalent to primers IHHNV389F/R. The detection limit for IHHNV309F/R was 100 copies when cloned plasmid DNA was used as the template (data not shown). Forty clinical samples from Hawaii (2004 and 2005) and Mexico (2005) were used to compare the sensitivity between these 2 pairs of primers: 32 samples tested positive for IHHNV with IHHNV389F/R, and 29 samples were found positive with IHHNV309F/R (35 cycles of amplification). We increased the number of cycles from 35 to 40 for the PCR assay using primers IHHNV309F/R in order to re-test 16 samples (including the 3 samples missed by IHHNV309F/R with 35 cycles), and all 16 samples were detected by primers IHHNV309F/R and IHHNV389F/R (Fig. 5). Thus, primers IHHNV309F/R can also be used for routine detection of IHHNV.

The black tiger prawn Penaeus monodon was once the dominant species of the shrimp farming industry in the eastern Hemisphere. Total aquaculture production of $P$. monodon increased to a high of 676000 tons in 2001 (Kongkeo 2005). Production of P. monodon has declined since 2002, particularly in Thailand and Indonesia, owing to the outbreak of viral diseases and the decision by many farmers to switch to the produc- tion of SPF Litopenaeus vannamei. Nevertheless, black tiger prawn is still the most highly valued species. Because SE Asian stocks are frequently infected with white spot syndrome virus (WSSV), yellow head virus (YHV), monodon baculovirus (MBV) or IHHNV, developers of SPF P. monodon have been collecting wild stock from elsewhere. Stocks from some areas of Australia were also infected with viruses, such as gill-associated virus (GAV) or mourilyan virus (MoV) (Cowley et al. 2000, 2005). Africa remains one of the few regions from which major shrimp viruses have not been reported, and where wild shrimp are often used for the development of SPF broodstock (Wyban et al. 1992).

Samples of Penaeus monodon from Africa are usually found to contain IHHNV-related sequences in their genome, but IHHNV infection has not been detected (Tang et al. 2003, Tang \& Lightner 2006). Several IHHNV PCR assays, such as those using primers IHHNV389F/R and IHHNV392F/R that are usually used for IHHNV detection in infected Litopenaeus vannamei and L. stylirostris (OIE 2003), are known to react with genomic IHHNV-related sequences. Some commercial kits such as IQ2000 also react with IHHNV-related sequences, especially with the Type B sequence that only differs by $8 \%$ from the nucleotide sequence of IHHNV. This often results in the unnecessary sacrifice of $P$. monodon that are wrongfully diag- 
nosed as being infected with IHHNV. Therefore, the development of a sensitive PCR method that can discriminate IHHNV-related sequences from the actual virus will be valuable in the development of SPF $P$. monodon stocks.

Acknowledgements. This study was supported by the Gulf Research Laboratory Consortium Marine Shrimp Farming Program, Co-operative State Research Service, US Department of Agriculture. We thank anonymous shrimp growers for providing $P$. monodon samples from Africa, Australia, and the Andaman Sea.

\section{LITERATURE CITED}

Bell TA, Lightner DV (1984) IHHN virus: infectivity and pathogenicity studies in Penaeus stylirostris and Penaeus vannamei. Aquaculture 38:185-194

Bonami JR, Trumper B, Mari J, Brehelin M, Lightner DV (1990) Purification and characterization of the infectious hypodermal and hematopoietic necrosis virus of penaeid shrimps. J Gen Virol 71:2657-2664

Cowley JA, Dimmock CM, Spann KM, Walker PJ (2000) Detection of Australian gill-associated virus (GAV) and lymphoid organ virus (LOV) of Penaeus monodon by RTnested PCR. Dis Aquat Org 39:159-167

Cowley JA, McCulloch RJ, Rajendran KV, Cadogan LC, Spann KM, Walker PJ (2005) RT-nested PCR detection of Mourilyan virus in Australia Penaeus monodon and its tissue distribution in healthy and moribund prawns. Dis Aquat Org 66:91-104

Fauquet CM, Mayo MA, Maniloff J, Desselberger U, Ball LA (2005) Virus taxonomy. Classification and nomenclature of viruses. 8th report of the International Committee on Taxonomy of Viruses. Elsevier Academic Press, San Diego, CA

Kalagayan G, Godin D, Kanna R, Hagino G, Sweeney J, Wyban J, Brock J (1991) IHHN virus as an etiological factor in runt-deformity syndrome of juvenile Penaeus vannamei cultured in Hawaii. J World Aquacult Soc 22: 235-243

Kongkeo H (2005) Cultured aquatic species information programme-Penaeus monodon. Cultured aquatic species fact sheets. FAO, Rome

Krabsetsve K, Cullen BR, Owens L (2004) Rediscovery of the Australian strain of infectious hypodermal and hematopoietic necrosis virus. Dis Aquat Org 61:153-158

Editorial responsibility: Timothy Flegel,

Bangkok, Thailand
Lightner DV, Redman RM, Bell TA (1983a) Detection of IHHN virus in Penaeus stylirostris and P. vannamei imported into Hawaii. J World Maricult Soc 14:212-225

Lightner DV, Redman RM, Bell TA (1983b) Infectious hypodermal and hematopoietic necrosis, a newly recognized virus disease of penaeid shrimp. J Invertebr Pathol 42: $62-70$

Morales-Covarrubias MS, Nunan LM, Lightner DV, MotaUrbina JC, Carza-Aguirre MC, Chavez-Sanchez MC (1999) Prevalence of infectious hypodermal and hematopoietic necrosis virus (IHHNV) in wild adult blue shrimp Penaeus stylirostris from the northern gulf of California, Mexico. J Aquat Anim Health 11 296-301

OIE (Office International des Epizooties) (2003) International aquatic animal health manual. Office International des Epizooties, Paris

Peyret N, Seneviratne PA, Allawi HT, SantaLucia J Jr (1999) Nearest-neighbor thermodynamics and NMR of DNA sequences with internal A.A, C.C, G.G, and T.T mismatches. Biochemistry 38:3468-3477

Primavera JH, Quinitio ET (2000) Runt-deformity syndrome in cultured giant tiger prawn Penaeus monodon. J Crustac Biol 20:796-802

SantaLucia J Jr (1998) A united view of polymer, dumbbell and oligonucleotide DNA nearest-neighbor thermodynamics. Proc Natl Acad Sci USA 95:1460-1465

Shike H, Dhar AK, Burns JC, Shimizu C, Jousset FX, Klimple KR, Bergoin M (2000) Infectious hypodermal and hematopoietic necrosis virus of shrimp is related to mosquito brevidensoviruses. Virology 277:167-177

Tang KFJ, Lightner DV (2002) Low sequence variation among isolates of infectious hypodermal and hematopoietic necrosis virus (IHHNV) originating from Hawaii and the Americas. Dis Aquat Org 49:93-97

Tang KFJ, Lightner DV (2006) Infectious hypodermal and hematopoietic necrosis virus (IHHNV)-related sequences in the genome of the black tiger prawn Penaeus monodon from Africa and Australia. Virus Res 118:185-191

Tang KFJ, Poulos BT, Wang J, Redman RM, Shih HH, Lightner DV (2003) Geographic variations among infectious hypodermal and hematopoietic necrosis virus (IHHNV) isolates and characteristics of their infection. Dis Aquat Org 53:91-99

Wyban JA, Swingle JS, Sweeney JN, Pruder GD (1992) Development and commercial performance of high health shrimp using specific pathogen free (SPF) broodstock Penaeus vannamei. In: Wyban J (ed) Proceedings of the specific session on shrimp farming. World Aquaculture Society, Baton Rouge, LA, p 254-259

Submitted: April 17, 2006; Accepted: November 16, 2006 Proofs received from author(s): February 14, 2007 